Angew Chem Int Ed Engl. 2009 ; 48(49): 9295-9299. doi:10.1002/anie.200903655.

\title{
Coencapsulation of Arsenic- and Platinum-based Drugs for Targeted Cancer Treatment
}

\author{
Haimei Chen \\ Chemistry of Life Processes Institute Northwestern University Evanston, IL 60208 \\ Samuel Pazicni \\ Department of Chemistry and Biophysics University of Michigan Ann Arbor, MI 48109 \\ Prof. Nancy L. Krett \\ Robert H. Lurie Comprehensive Cancer Center Northwestern University Chicago, IL 60611 \\ Richard W. Ahn \\ Chemistry of Life Processes Institute Northwestern University Evanston, IL 60208 \\ Prof. James E. Penner-Hahn \\ Department of Chemistry and Biophysics University of Michigan Ann Arbor, MI 48109 \\ Prof. Steven T. Rosen \\ Robert H. Lurie Comprehensive Cancer Center Northwestern University Chicago, IL 60611 \\ Prof. Thomas V. O'Halloran* \\ Chemistry of Life Processes Institute Northwestern University Evanston, IL 60208
}

\section{Keywords}

arsenic trioxide; cisplatin; liposome; coencapsulation; targeted delivery

\begin{abstract}
Arsenic- and platinum-based drugs are highly potent but also toxic agents used in cancer therapy.[1,2] Arsenic trioxide (Trisenox ${ }^{\circledR}, \mathrm{As}_{2} \mathrm{O}_{3}$ ) is a front-line drug for treatment of acute promyelocytic leukemia[3] and is in clinical trials for treatment of other malignancies, including multiple myeloma.[4] However, clinical outcomes of $\mathrm{As}_{2} \mathrm{O}_{3}$ in solid tumors have been poor in many cases,[1,5] mainly due to limited bioavailability of the drug in the tumor site. Clinical application to solid tumors is also impeded by toxicity including neutropenia, liver failure and cardiac toxicity [1,6] at higher doses.[7] Cisplatin (cis-diamine dichloroplatinum $^{\mathrm{II}}$, cisPt, Figure 1a) is commonly used in the treatment of a variety of solid tumors, including lung, ovarian, bladder, and testicular cancer.[2] The active intracellular species appear to be the hydrolyzed monoaqua- and diaqua-cisplatin (aqua-cisPt, Figure 1a). [8] Broader therapeutic applications of cisPt are limited by serious systemic toxicities, development of drug resistance, and rapid inactivation of the drug due to complexation with plasma and tissue proteins.[2,8] These problems can be reduced by using a drug delivery system that prevents drug deactivation, extends the circulation time of drug in blood and increases its accumulation at tumor sites.[9] Lipid-based carriers have been successfully applied in clinics for improving the therapeutic efficacy of numerous drugs, such as liposomal doxorubicin (Doxil@),[10] mainly via the enhanced permeability and retention (EPR) effects.[9]
\end{abstract}

\footnotetext{
${ }^{[*}$ Fax: (+) 1-847-491-7713 t-ohalloran@ @orthwestern.edu.

Supporting information for this article is available on http://www.angewandte.org or from the author.
} 
Several liposomal formulations of cisPt have been prepared, including STEALTH SPI-077, [11] and negative-lipid coated cisPt nanocapsules;[12] however, their clinical applications have been hindered by low encapsulation efficiencies ( 0.02 Pt-to-lipid molar ratio) which limits bioavailability,[13,14] and poor serum stability (lifetime $<1$ hour).[15] Preparations of liposomal $\mathrm{As}_{2} \mathrm{O}_{3}$ have also faced challenges because the neutral $\mathrm{As}(\mathrm{OH})_{3}$ species (which is predominant at $\mathrm{pH}<9.0)[16]$ diffuses readily across lipid membranes,[17] thus making stable drug-encapsulation difficult.[18] Recently, the latter issues were overcome via development of an efficient system for loading high densities of $\mathrm{As}_{2} \mathrm{O}_{3}$ nanoparticles into liposomes ( 0.5 drug-to-lipid molar ratio) with excellent retention (shelf life $>6$ months) and good serum stability.[17,19] This system employs transmembrane gradients of transition metal ions to produce $\mathrm{As}_{2} \mathrm{O}_{3}$-nanoparticles within liposomes. These nanoparticulate forms of the drug encapsulated in liposomes (denoted as "nanobin" for short) exhibit enhanced anticancer efficacy relative to the parent drug in both breast cancer and lymphoma xenograft, as well as reduced systemic toxicity (R. W. Ahn, et al. we shall report on this in detail later). Here we report on expanding this strategy to the stable and efficient coencapsulation of both arsenic- and platinum-based drugs in a single vesicle. This approach ameliorates systemic toxicity of both drugs and allows for enhanced antitumor efficacy and specificity through targeted delivery of anticancer drug combinations to specific tumor cells.

We first prepared $300 \mathrm{mM}$ aqua-cisPt acetate ( $\mathrm{pH}$ 5.1, with cis- $\left.\left(\mathrm{NH}_{3}\right)_{2} \mathrm{Pt}\left(\mathrm{OH}_{2}\right)_{2}\right]^{2+}$ species predominant[20]) as previously described.[21] The dry lipid film (dipalmitoylphosphatidylcholine(DPPC)/dioleoylphosphatidylglycerol(DOPG)/ cholesterol $(\mathrm{Chol})=51.4 / 3.6 / 45 \mathrm{~mol} \%$ ) was hydrated in this solution and extruded to $100-\mathrm{nm}$ diameter (Figures 1 and S1). The acetate solution of aqua-cisPt was chosen as the intraliposomal medium because we previously found that acetate anions in the liposomal nickel acetate were critical for arsenic loading.[17] Other platinum complexes, such as monoaqua-cisPt acetate and aqua-cisPt carbonate, have too low aqueous solubility $(<15$ $\mathrm{mM}$ ) to be used here. The extraliposomal platinum was then removed by gel filtration, forming a gradient of aqua-cisPt acetate from the internal to the external aqueous phase of the liposomes (Figure $\mathrm{S} 1$ ). Addition of concentrated $\mathrm{As}_{2} \mathrm{O}_{3}$ solution at $\mathrm{pH}$ 6.6, resulted in active loading of $\mathrm{As}(\mathrm{OH})_{3}$ into the liposome with $t_{1 / 2} \approx 40 \mathrm{~min}$ at $50^{\circ} \mathrm{C}$, giving final molar ratios of As/lipid $0.63 \pm 0.05$ and Pt/lipid $0.48 \pm 0.06$ after $11 \mathrm{~h}(\mathrm{n}=7$, the number of independent experiments). The nanoparticle formation mechanism appears to involve in the influx of $\mathrm{As}(\mathrm{OH})_{3}$ followed by complexation with aqua-cisPt species (Figure 1b), as occured in the arsenic loading process for liposomal nickel acetate.[17] [22] The extraliposomal pH dropped from 6.6 to 6.0 after $11 \mathrm{~h}$, indicating proton release from liposomal cores that may be through deprotonation of aqua-cisPt/As $(\mathrm{OH})_{3}$ upon coordination. Quantitative analysis indicate that one liposomal core (liposome mean size $=112 \pm 9 \mathrm{~nm}$ ) can be loaded with $\sim 12$ $\times 10^{4}$ As atoms and $\sim 9 \times 10^{4} \mathrm{Pt}$ atoms, with intraliposomal concentratrions of $\sim 390 \mathrm{mM}$ arsenic and $\sim 300 \mathrm{mM}$ platinum via this method (see Supplementary Information). Large scale uniform batches of arsenic and platinum co-loaded liposomes, denoted as NB(As, Pt), were prepared at various drug payload levels depending on concentration of aqua-cisPt acetate (Figures S1-2). The aqua-cisPt loaded liposomes are denoted as NB(Pt).

The transmission electron microscopy (TEM) and energy-dispersive X-ray analysis (EDX) [23] reveal the presence of As and Pt cores within NB(As, Pt) with high electronic density (Figure 2e). We isolated these inorganic nanoparticles (pale yellow, air-stable) from the lipid shell, allowing for analysis by X-ray photoelectron spectroscopy (XPS, Figure S10 and Table S3). The XPS As(3d) $(44.9 \pm 0.5 \mathrm{eV})$ and $\operatorname{Pt}\left(4 \mathrm{f}_{7 / 2}\right)(73.5 \pm 0.4 \mathrm{eV})$ chemical shifts indicated that the As and $\mathrm{Pt}$ species remained $\mathrm{As}{ }^{\mathrm{III}}$ and $\mathrm{Pt}^{\mathrm{II}}$. The $\mathrm{NB}(\mathrm{As}, \mathrm{Pt})$ in the aqueous buffer were also analyzed by X-ray absorption spectroscopy (XAS). The X-ray absorption edge energies corroborate the XPS oxidation state assignments of $\mathrm{As}^{\mathrm{III}}$ and $\mathrm{Pt}^{\mathrm{II}}$, and extended X-ray absorption fine structure (EXAFS) data provide direct evidence for an 
intimate interaction between $\mathrm{As}(\mathrm{OH})_{3}$ and aqua-cisPt within the liposome (Figures $2 \mathrm{~g}$ and S11, best fit results summarized in Tables S4-5). The As K edge EXAFS is modeled by an As-O shell at $1.72 \AA$ and an As-Pt shell at $2.33 \AA$. Because the As K edge overlaps the Pt $\mathrm{L}_{\text {III }}$ EXAFS and prevents the collection of Pt $\mathrm{L}_{\mathrm{III}}$ data to high $k$, we also measured Pt $\mathrm{L}_{\mathrm{II}}$ EXAFS. Both the $\mathrm{L}_{\mathrm{III}}$ and $\mathrm{L}_{\mathrm{II}}$ data are consistent with the As EXAFS; fits to the $\mathrm{L}_{\mathrm{III}}$ data give a Pt-(N/O) shell at $2.00 \AA$ and a Pt-As shell at $2.32 \AA$ (Table S5). The fact that As-Pt and Pt-As both have apparent coordination numbers of $\sim 1$ indicates that most of the As and $\mathrm{Pt}$ atoms are in a dinuclear complex. The short As-Pt distances indicate $\mathrm{As}(\mathrm{OH})_{3}$ is coordinated to Pt through As where the As ${ }^{\mathrm{III}}$ donated its lone pair to form a Lewis adduct with $\mathrm{Pt}^{\mathrm{II}}$ (Figure S11b). Similar coordinations of $\mathrm{As}(\mathrm{OH})_{3}$ as a lewis base to metal ions have been reported for other heterometallic complexes, including $\left[\mathrm{Mo}_{3} \mathrm{PdAs}(\mathrm{OH})_{3} \mathrm{~S}_{4} \mathrm{Cl}_{3}-\left(\mathrm{OH}_{2}\right)_{6}\right]$, $[24]\left[\mathrm{W}_{3}\left(\mathrm{NiAs}(\mathrm{OH})_{3}\right) \mathrm{S}_{4}\left(\mathrm{H}_{2} \mathrm{O}\right)_{8} \mathrm{Cl}\right]^{3+},[25]$ and arsine complex

$\left[\mathrm{PtCl}_{2}\left[\mathrm{As}\left(\mathrm{CH}_{2} \mathrm{CMe}=\mathrm{CH}_{2}\right)_{3}\right]_{2}\right]$,[26] with the As-Pd, As-Ni and As-Pt distances of 2.23-2.37 $\AA$. Formation of a Pt-As sigma bond upon $\mathrm{As}(\mathrm{OH})_{3}$ substitution for the $\mathrm{OH}_{2}$ of aqua-cisPt may partially account for the retention of $\mathrm{As}^{\mathrm{III}}$ within liposomes (Figure 3).

In the absence of arsenic, the aqueous solution of aqua-cisPt acetate alone was unstable with or without liposomes and changed into brown and then black after one month at $4{ }^{\circ} \mathrm{C}$, perhaps due either to photosensitivity[27] or to the formation of platinum carbonato complexes upon absorption of $\mathrm{CO}_{2}$ from air.[28] The co-encapsulation strategy described here provides a way of stably sequestering both arsenic and platinum drugs within liposomal cores: drug release studies reveal high stability of $\mathrm{NB}(\mathrm{As}, \mathrm{Pt})$ under physiologically relevant conditions. Less than $17 \%$ of the drugs were released over a 21 -month storage at $4^{\circ} \mathrm{C}$ (Figure 3a). When $\mathrm{NB}\left(\mathrm{As}, \mathrm{Pt}\right.$ ) were kept at $37^{\circ} \mathrm{C}, \mathrm{pH} 7.4$ for 3 days (Figure S3a), only $5 \%$ of the drugs were released. Although the solid complex(As, $\mathrm{Pt}$ ) tends to hydrolyze when $\mathrm{pH}$ $>6.0$ (Figure $\mathrm{S} 9$ ), it is less sensitive to extraliposomal $\mathrm{pH}$ once sequestered within the liposome.

In addition, the low drug release rate in serum suggest that $\mathrm{NB}(\mathrm{As}, \mathrm{Pt})$ possess significant stability upon intervenous administration. The presence of a serum challenge (at $\mathrm{pH}$ 7.4) only slightly increased the drug release $\left(20 \%\right.$ drug release after 3 days at $37^{\circ} \mathrm{C}$, Figure $3 \mathrm{~b}$, $\mathrm{DPPC} / \mathrm{DOPG} / \mathrm{Chol}=51.4 / 3.6 / 45 \mathrm{~mol} \%$ ). Upon reducing membrane stability of $\mathrm{NB}(\mathrm{As}, \mathrm{Pt}$ ) by lowering the cholesterol content[29] of the lipid bilayer (DPPC/DOPG/Chol mol\%) from 51.4/3.6/45 to 86.4/3.6/10 and 96.4/3.6/0, we found the drug release in serum was 30\% As and 13\% Pt for the 86.4/3.6/10 composition (Figure S4b), and 41\% As and 23\% Pt for the 96.4/3.6/0 composition (Figure S4c), three times faster than those (12\% As and $0.5 \% \mathrm{Pt}$ release) of the 51.4/3.6/45 composition (Figure $3 \mathrm{~b}$ ) after $24 \mathrm{~h}$ at $37^{\circ} \mathrm{C}$. The faster drug release led to higher cytotoxic effects of $\mathrm{NB}(\mathrm{As}, \mathrm{Pt})$ against SU-DHL-4 human lymphoma and MDA-MB-231 human breast cancer cells (Figures S4d-e): the $\mathrm{IC}_{50}$ (As level) of the 96.4/3.6/0 composition was $4.0 \mu \mathrm{M}$ for SU-DHL-4 and $10.5 \mu \mathrm{M}$ for MDA-MB-231 cells, three times lower than those of the 51.4/3.6/45 composition (13.6 $\mu \mathrm{M}$ and $27.7 \mu \mathrm{M}$, respectively) after a 72 or $96 \mathrm{~h}$ treatment. The drug bio-availability appears to result from gradual dissociation of arsenic and platinum nanoparticulates into active $\mathrm{As}(\mathrm{OH})_{3}$ and [cis$\left.\left(\mathrm{NH}_{3}\right)_{2} \mathrm{Pt}\left(\mathrm{OH}_{2} / \mathrm{OH}\right)_{2}\right]^{\mathrm{n}+}$ species which diffuse from liposomes into cellular environments.

The activity of $\mathrm{NB}(\mathrm{As}, \mathrm{Pt})$ with the 51.5/3.6/45 composition against a panel of human tumor cell lines of lymphoma SU-DHL-4 and IM-9, breast cancer MDA-MB-231, ovarian cancer OVCAR-3 and multiple myeloma MM.1S, was compared with those of $\mathrm{NB}(\mathrm{Pt}), \mathrm{As}_{2} \mathrm{O}_{3}$, aqua-cisPt, and cisPt under the same conditions (Tables 1 and S1, Figures S6-8). In general, both $\mathrm{NB}(\mathrm{As}, \mathrm{Pt})$ and $\mathrm{NB}(\mathrm{Pt})$ show attenuated cytotoxicities relative to free $\mathrm{As}_{2} \mathrm{O}_{3}$, aquacisPt, and cisPt (Tables 1 and S1). This indicates that liposome coencapsulation lowers general toxicity of both arsenic and platinum drugs in vivo. Notably, $\mathrm{NB}(\mathrm{As}, \mathrm{Pt})$ was more cytotoxic (3-7 fold) than $\mathrm{NB}(\mathrm{Pt})$, indicating the bioavailability of both arsenic and platinum 
species from $\mathrm{NB}(\mathrm{As}, \mathrm{Pt})$. The cytotoxicity of $\mathrm{NB}(\mathrm{As}, \mathrm{Pt})$ increased gradually over time, approaching those of free drugs at long incubation times (> $72 \mathrm{~h}$, Figures S6-7), consistent with the gradual drug release over time at $37^{\circ} \mathrm{C}$ in serum (Figure $3 \mathrm{~b}$ ).

This system for co-loading arsenic and platinum drugs presents a robust platform for further optimization by conjugation with specific ligands or antibodies to target specific tumors. To examine the efficacy of a targeted version of this dual-acting agent, we used folate- $\mathrm{PEG}_{3350^{-}}$ DSPE (folic acid conjugated with polyethyleneglycol[MW3350]-derivatized distearoylphosphatidyl-ethanolamine) as a targeting ligand[30] (Figure 4). Folic acid and its derivatives have been used as effective targeting ligands for treatment of certain tumors because the folate receptor (FR) is often overexpressed in malignant tissues.[31] A small amount of folate- $\mathrm{PEG}_{3350}$-DSPE was mixed with the preformed NB(As, $\mathrm{Pt}$ ) at an initial folate/lipid molar ratio of $0.7 \%, 50^{\circ} \mathrm{C}$ for $1.5 \mathrm{~h}$ (Figure 4). This allowed the two chains of the DSPE moiety to insert into the lipid shell with the Folate- $\mathrm{PEG}_{3350}$ moiety in the external leaflet of $\mathrm{NB}(\mathrm{As}, \mathrm{Pt})$ to be available for targeting. Such a "post-insertion" process[32] caused little liposomal drug release $(<6 \%)$, and allowed for high incorporation efficiency (80\%), giving a folate/lipid molar ratio of $0.56 \%$. After post-insertion, the mean diameter $(129 \pm 4 \mathrm{~nm})$ of folate-targeted arsenic and platinum liposomes (f-NB(As, Pt)) was incresed by $17 \mathrm{~nm}$, relative to that of $\mathrm{NB}(\mathrm{As}, \mathrm{Pt})(112 \pm 9 \mathrm{~nm})$.

These folate-targeted f-NB(As, Pt) exhibit efficient cellular uptake and anti-cancer activities to FR-positive tumor cells. Confocal microscopy studies indicated significant uptake of $f$ $\mathrm{NB}$ (As, Pt) via FR-mediated endocytosis into $\mathrm{FR}^{+} \mathrm{KB}$ (human nasopharyngeal), but not $\mathrm{FR}^{-}$MCF-7 (human breast) tumor cells $[19,33]$ after $3 \mathrm{~h}$ at $37^{\circ} \mathrm{C}$ (Figures 5a-d).

Quantitative analysis also revealed substantial accumulation of f-NB(As, Pt) within KB cells $\left(131 \times 10^{7} \mathrm{As}\right.$ atoms/cell, $109 \times 10^{7} \mathrm{Pt}$ atoms/cell $), 8-270$ times higher than those of $\mathrm{NB}$ (As, Pt) $\left(3 \times 10^{7}\right.$ As atoms/cell, $0.3 \times 10^{7} \mathrm{Pt}$ atoms/cell $), \mathrm{As}_{2} \mathrm{O}_{3}\left(17 \times 10^{7}\right.$ As atoms/cell $)$ and aqua-cisPt $\left(0.4 \times 10^{7} \mathrm{Pt}\right.$ atoms/cell) (Figure 5e and Table S2). Accordingly, the cytoxic effect of $\mathrm{f}-\mathrm{NB}(\mathrm{As}, \mathrm{Pt})$ on $\mathrm{KB}$ cells was significantly enhanced relative to those of $\mathrm{NB}(\mathrm{As}$, Pt) (> 60 fold), $\mathrm{As}_{2} \mathrm{O}_{3}$ (> 60 fold), and aqua-cisPt (4 fold) at $3 \mathrm{~h}$ (Figure 5f). The potentiation of $\mathrm{f}-\mathrm{NB}(\mathrm{As}, \mathrm{Pt})$ versus $\mathrm{NB}(\mathrm{As}, \mathrm{Pt})$ decreased at a 72 -h drug treatment (Table 2), probaly due to non-specific cellular liposome association and/or passive drug release: both would contribute to the cytotoxicity of $\mathrm{NB}(\mathrm{As}, \mathrm{Pt})$. The addition of $2 \mathrm{mM}$ free folic acid (FA, as a competitive ligand for $\mathrm{f}-\mathrm{NB}(\mathrm{As}, \mathrm{Pt})$ targeting) resulted in a dramatic decrease of cytotoxic effects for f-NB(As, Pt) (Figure 5b, e, f), consistant with FR-mediated efficacy. In contrast, for $\mathrm{FR}^{-}$MCF-7 cells, f-NB(As, Pt) didn't show significantly increased anticancer efficacy relative to $\mathrm{NB}(\mathrm{As}, \mathrm{Pt}$ ) and free drugs, consistent with its low cellular uptake (Figure 5e). As shown in Table 1, liposome encapsulation reduces general toxicity of arsenic and platinum drugs, and thus we anticipate few off-target interations and lower systemic toxicity. When such drug-loaded liposomes are further linked to a targeting ligand, such as folate, and delivered into tumor cells through receptor-mediated endocytosis (Figure 5a), an efficient cytosolic unloading of liposomal drug contents can be achieved through enzymatic degradation[34] and thus accelerate the biological actions of drugs. This may account for the significantly enhanced anti-cancer efficacy of f-NB(As, Pt) relative to free drugs.

In summary, we have developed a strategy for efficiently co-encapsulating arsenic- and platinum-based drugs into $100-\mathrm{nm}$-scale liposomes by combining passive and active loading methods. The nanoparticulate form of two drugs within liposomes is stabilized by a new type of As ${ }^{\mathrm{III}}-\mathrm{Pt}^{\mathrm{II}}$ adduct. The resultant therapeutic agent shows a long shelf life $(<17 \%$ release over a 21 -month period at $\left.4^{\circ} \mathrm{C}\right)$ and is stable in serum $(<20 \%$ drug release after $72 \mathrm{~h}$ at $37^{\circ} \mathrm{C}$ ), suggesting a long circulation time in vivo. Coordinating the release rates of both drugs can be achieved by altering the lipid composition, which thus modulates the bioactivity of $\mathrm{NB}(\mathrm{As}, \mathrm{Pt})$. These stably co-encapsulated arsenic and platinum drugs exhibit 
attenuated cellular toxicity towards both hematological cancer and solid tumors derived cells, relative to free $\mathrm{As}_{2} \mathrm{O}_{3}$, aqua-cisPt, and cisPt. Targeted delivery of co-encapsulated arsenic and platinum drugs by folate significantly enhanced the cellular uptake and thus anticancer efficacy against FR-overexpressing tumor cells. Such arsenic and platinum "nanobins" can be used for direct therapeutic trials and also for further surface modifications with other targeting agents that recognize specific types of cancer, and hold the promise of improving the therapeutic index and profile for both drugs. Further modification with a pHsensitive polymer coating[35] presents an alternative approach for optimizing the bioactivity of co-encapsulated agents. The coencapsulation strategy developed in this report will be expanded to other conventional chemotherapeutic drugs and their synergistic agents.

\section{Supplementary Material}

Refer to Web version on PubMed Central for supplementary material.

\section{Acknowledgments}

This work was supported by National Institutes of Health (GM054111 and GM038047), the Center of Cancer Nanotechnology Excellence (U54CA119341), the CDMRP Breast Cancer Research Program (BC073413 and BC076723). Thanks to Prof. David H. Thompson (Purdue University) for providing folate-PEG3350-DSPE, Rebecca Marvin for help with ICP-MS, Prof. Robert C. MacDonald for critical reading, Sang-Min Lee and Dr. Mala Shanmugam for advice.

\section{References}

[1]. Dilda PJ, Hogg PJ. Cancer Treat. Rev. 2007; 33:542-564. [PubMed: 17624680]

[2]. Kelland L. Nature Reviews Cancer. 2007; 7:573-584.

[3]. Wang ZY, Chen Z. Blood. 2008; 111:2505-2515. [PubMed: 18299451]

[4]. Berenson R, Yeh HS. Clin. Lymphoma Myeloma. 2006; 7:192-198. [PubMed: 17229334]

[5]. Chen Z, Chen GQ, Shen ZX, Sun GL, Tong JH, Wang ZY, Chen SJ. Semin. Hematol. 2002; 39:22-26. [PubMed: 12012319]

[6]. Evens AM, Tallman MS, Gartenhaus RB. Leuk. Res. 2004; 28:891-900. [PubMed: 15234563]

[7]. Liu B, Pan S, Dong X, Qiao H, Jiang H, Krissansen GW, Sun X. Cancer Sci. 2006; 97:675-681. [PubMed: 16827809]

[8]. Wang D, Lippard SJ. Nat. Rev. Drug Discov. 2005; 4:307-320. [PubMed: 15789122]

[9]. Allen TM, Cullis PR. Science. 2004; 303:1818-1822. [PubMed: 15031496]

[10]. Gabizon AA. Cancer Invest. 2001; 19:424-436. [PubMed: 11405181]

[11]. Peleg-Shulman T, Gibson D, Cohen R, Abra R, Barenholz Y. Biochim. Biophys. Acta. 2001; 1510:278-291. [PubMed: 11342165]

[12]. Burger Koert NJ, Staffhorst Rutger WHM, de Vijlder Hanke C, Velinova Maria J, Bomans Paul H, Frederik Peter M, de Kruijff B. Nat Med. 2002; 8:81-84. [PubMed: 11786911]

[13]. Harrington KJ, Lewanski CR, Northcote AD, Whittaker J, Wellbank H, Vile RG, Peters AM, Stewart JS. Ann. Oncol. 2001; 12:493-496. [PubMed: 11398881]

[14]. Bandak S, Goren D, Horowitz A, Tzemach D, Gabizon A. Anti-Cancer Drugs. 1999; 10:911920. [PubMed: 10630359]

[15]. Velinova MJ, Staffhorst RWHM, Mulder WJM, Dries AS, Jansen BAJ, de Kruijff B, de Kroon AIPM. Biochimica et Biophysica Acta, Biomembranes. 2004; 1663:135-142.

[16]. Ni Dhubhghaill OM, Sadler PJ. Struct. Bonding (Berlin). 1991; 78:129-190.

[17]. Chen H, MacDonald RC, Li S, Krett NL, Rosen ST, O'Halloran TV. Journal of the American Chemical Society. 2006; 128:13348-13349. [PubMed: 17031934]

[18]. Kallinteri P, Fatouros D, Klepetsanis P, Antimisiaris SG. J. Liposome Res. 2004; 14:27-38. [PubMed: 15461930]

[19]. Chen H, Ahn R, Bossche J. V. d. Thompson DH, O'Halloran TV. Mol. Cancer Ther. 2009; 8(7) 
[20]. Berners-Price SJ, Frenkiel TA, Frey U, Ranford JD, Sadler PJ. J. Chem. Soc., Chem. Commun. 1992:789-791.

[21]. Appleton TG, Berry RD, Davis CA, Hall JR, Kimlin HA. Inorg. Chem. 1984; 23:3514-3521.

[22]. Lide D. Handbook of Chemistry and Physics. 2002; 83rd(8):46-48.

[23]. Meldrum FC, Wade VJ, Nimmo DL, Heywood BR, Mann S. Nature. 1991; 349:684-687.

[24]. Sokolov MN, Virovets AV, Dybtsev DN, Chubarova EV, Fedin VP, Fenske D. Inorg. Chem. 2001; 40:4816-4817. [PubMed: 11531424]

[25]. Hernandez-Molina R, Sokolov MN, Clausen M, Clegg W. Inorg. Chem. 2006; 45:10567-10575. [PubMed: 17173411]

[26]. Phadnis PP, Jain VK, Klein A, Schurr T, Kaim W. New J. Chem. 2003; 27:1584-1591.

[27]. Perumareddi JR, Adamson AW. J. Phys. Chem. 1968; 72:414-420.

[28]. Lippert B, Lock CJL, Rosenberg B, Zvagulis M. Inorg. Chem. 1978; 17:2971-2975.

[29]. New, RRC. Rickwood, D., editor. Oxford University Press; New York: 1990. p. 19-22.

[30]. Rui Y, Wang S, Low PS, Thompson DH. J. Am. Chem. Soc. 1998; 120:11213-11218.

[31]. Low PS, Henne WA, Doorneweerd DD. Acc. Chem. Res. 2008; 41:120-129. [PubMed: 17655275]

[32]. Allen TM, Sapra P, Moase E. Cell. Mol. Biol. Lett. 2002; 7:889-894. [PubMed: 12378272]

[33]. Sonvico F, Dubernet C, Marsaud V, Appel M, Chacun H, Stella B, Renoir M, Colombo P, Couvreur P. J. Drug Del. Sci. Tech. 2005; 15:407-410.

[34]. Bareford M, Swaan PW. Adv. Drug. Deliv. Rev. 2007; 59:748-758. [PubMed: 17659804]

[35]. Lee S-M, Chen H, Dettmer CM, O'Halloran TV, Nguyen ST. Journal of the American Chemical Society. 2007; 129:15096-15097. [PubMed: 17999499] 


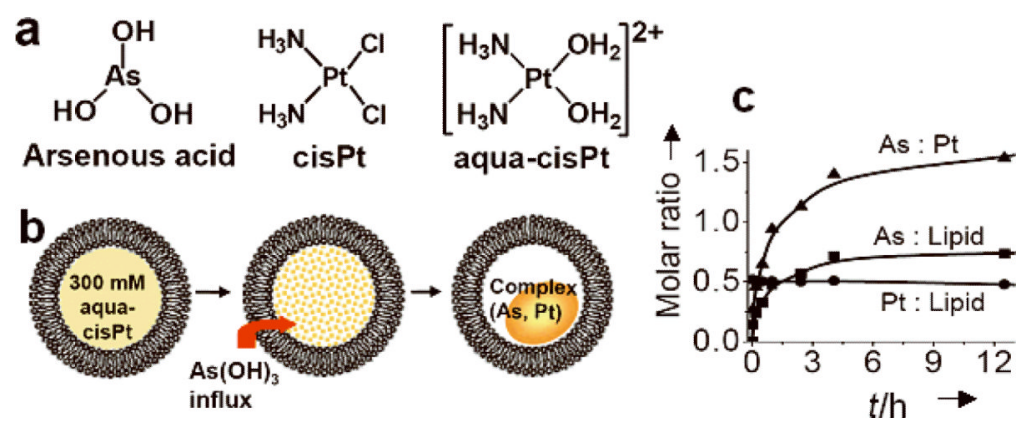

Figure 1.

a) Structures of arsenic and platinum drugs related in this study. b) Scheme of arsenic loading into a liposome in response to a transmembrane gradient of aqua-cisPt acetate ([cis$\left.\left.\left(\mathrm{NH}_{3}\right)_{2} \mathrm{Pt}\left(\mathrm{OH}_{2}\right)_{2}\right]^{2+}\right)$. c) The kinetics of arsenic loading into liposomes (DPPC/DOPG/Chol $=51.4 / 3.6 / 45 \mathrm{~mol} \%$ ) using $300 \mathrm{mM}$ aqua-cisPt acetate solution ( $\mathrm{pH} \mathrm{5.1)}$ ) as intraliposomal medium with an initial As-to-lipid molar ratio of 4.0 at $50^{\circ} \mathrm{C}$. 


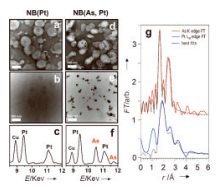

Figure 2.

TEM images and EDX spectra of $\mathrm{NB}(\mathrm{Pt})(\mathrm{a}, \mathrm{b}$ and $\mathrm{c})$ and $\mathrm{NB}(\mathrm{As}, \mathrm{Pt})(\mathrm{d}$, e and $\mathrm{f})$. Samples of $a$ and $d$ were stained by $2 \%$ uranyl acetate; $b$ and e are unstained, showing discrete electron-dense inorganic cores within liposomes; the single-particle EDX spectra $\mathrm{c}$ and $\mathrm{f}$ correspond to $\mathrm{b}$ and e, respectively, revealing $\mathrm{Pt}$ (c), $\mathrm{Pt}$ and $\mathrm{As}$ (f) cores. $\mathrm{Cu}$ peaks arise from the EM grid. (g) Phase-corrected EXAFS Fourier transforms for NB(As, Pt). DPPC/DOPG/ Chol $=51.4 / 3.6 / 45 \mathrm{~mol} \%$. 


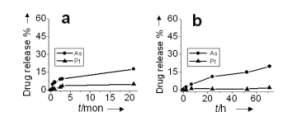

Figure 3.

Drug release of $\mathrm{NB}(\mathrm{As}, \mathrm{Pt})$ as the function of time under $4^{\circ} \mathrm{C}$ storage conditions (a), and at $37^{\circ} \mathrm{C}$ with $80 \%$ fetal bovine serum (FBS) (b). DPPC/DOPG/Chol = 51.4/3.6/45 mol\%. 


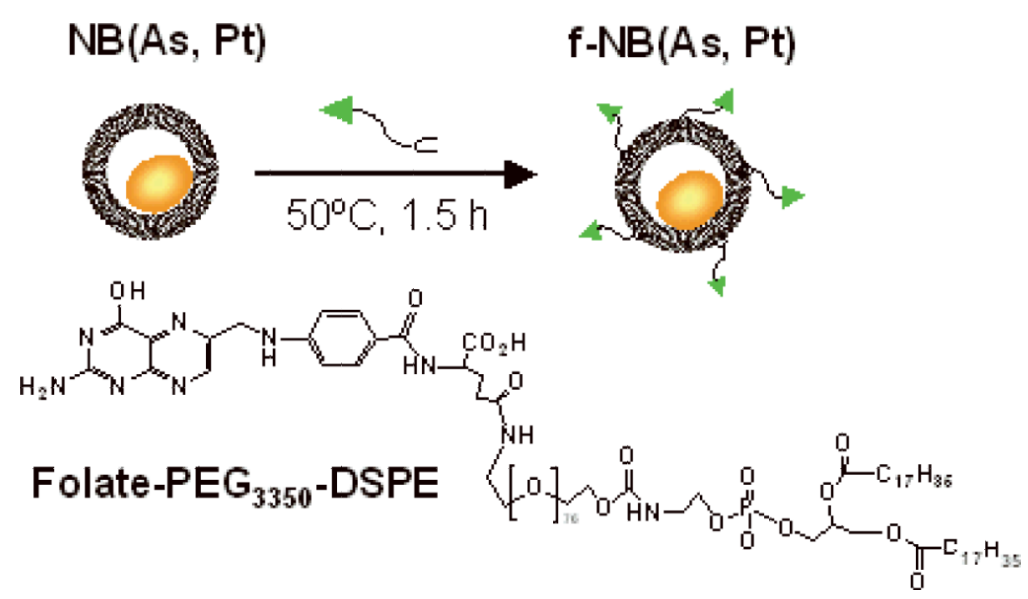

Figure 4.

Preparation of folate-targeted arsenic and platinum liposomes by post-insertion of targeting ligands (Folate-PEG 3350 -DSPE) into NB(As, Pt). DPPC/DOPG/Chol = 51.4/3.6/45 mol\%. 

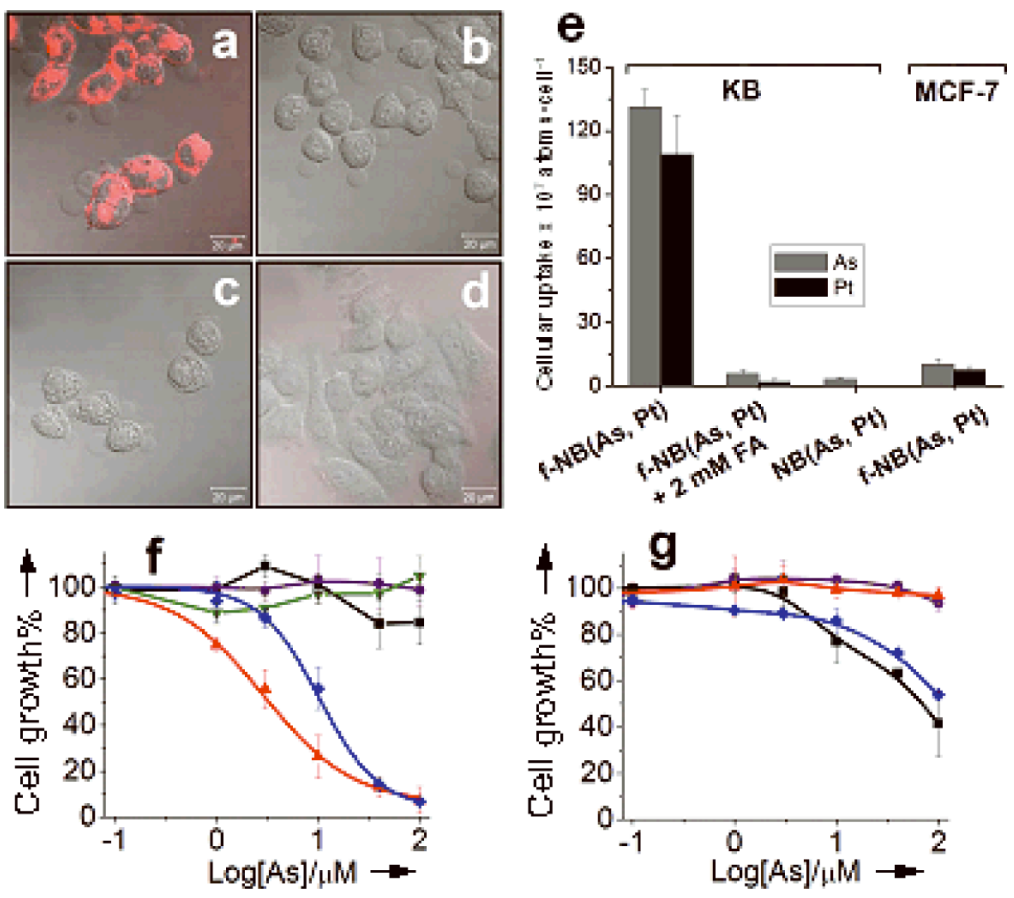

Figure 5.

Comparison of cellular drug uptake and cytotoxicity of various drug formulations. Confocal micrograghs (merged with DIC images) showing cellular uptake of (a) f-NB(As, Pt), (b) f$\mathrm{NB}(\mathrm{As}, \mathrm{Pt})+2 \mathrm{mM}$ FA, (c) NB(As, Pt) by KB cells, and of (d) f-NB(As, Pt) by MCF-7 cells after $3 \mathrm{~h}$ at $37^{\circ} \mathrm{C}$. Liposomes were labeled with rhodamine (Rh). Scale bar: $20 \mu \mathrm{m}$. e) $\mathrm{KB}$ and MCF-7 cellular arsenic and platinum uptake. Cytotoxic effects of f-NB(As, $\mathrm{Pt})(\boldsymbol{\Delta})$, $\mathrm{f}-\mathrm{NB}(\mathrm{As}, \mathrm{Pt})+2 \mathrm{mM} F A(\boldsymbol{\nabla}), \mathrm{NB}(\mathrm{As}, \mathrm{Pt})(\bullet), \mathrm{As}_{2} \mathrm{O}_{3}(\boldsymbol{\bullet})$ and aqua-cisPt $(\boldsymbol{)})$ towards $\mathrm{KB}$ (f) and MCF-7 (g) cells. Cells exposed to drugs at $37^{\circ} \mathrm{C}$ for $3 \mathrm{~h}$, washed by PBS and further incubated up to $72 \mathrm{~h}$ in drug-free medium. 


\section{Table 1}

Cytotoxicity $\left(\mathrm{IC}_{50}\right)$ of various platinum and arsenic formulations to human tumor cells

\begin{tabular}{|c|c|c|c|c|}
\hline \multirow[b]{2}{*}{ Cell lines $[a]$} & \multicolumn{4}{|c|}{$\mathrm{IC}_{50}(\mu \mathrm{M})^{[b]}$} \\
\hline & $\mathrm{NB}(\mathrm{As}, \mathrm{Pt})^{[c]}$ & $\operatorname{NB}(\mathbf{P t})^{[c]}(\mathbf{P t})$ & Aqua-cisPt (Pt) & $\mathrm{As}_{2} \mathrm{O}_{3}(\mathrm{As})$ \\
\hline SU-DHL-4 & $\begin{array}{l}20.6 \pm 3.6(\mathrm{As}) \\
15.6 \pm 2.8(\mathrm{Pt})\end{array}$ & $42.4 \pm 15.0$ & $5.5 \pm 0.4$ & $3.7 \pm 0.2$ \\
\hline IM-9 & $\begin{array}{l}5.0 \pm 0.6(\mathrm{As}) \\
3.8 \pm 0.4(\mathrm{Pt})\end{array}$ & $10.7 \pm 1.9$ & $1.0 \pm 0.01$ & $2.1 \pm 0.03$ \\
\hline MDA-MB-231 & $\begin{array}{l}35.0 \pm 7.4(\mathrm{As}) \\
26.6 \pm 5.6(\mathrm{Pt})\end{array}$ & $>200$ & $17.9 \pm 0.1$ & $10.0 \pm 2.4$ \\
\hline OVCAR-3 & $\begin{array}{l}8.8 \pm 1.6(\mathrm{As}) \\
6.6 \pm 1.2(\mathrm{Pt})\end{array}$ & $18.4 \pm 0.6$ & $2.6 \pm 0.8$ & $2.7 \pm 1.1$ \\
\hline \multicolumn{5}{|c|}{$[a] 48$ h-drug treatment for SU-DHL-4 and IM-9, and $72 \mathrm{~h}$-drug treatment for MDA-MB-231 and OVCAR-3 cells. } \\
\hline
\end{tabular}


Table 2

Cytotoxicity $\left(\mathrm{IC}_{50}\right)$ of folate-targeted arsenic and platinum liposomes to human tumor cells ${ }^{[a]}$

\begin{tabular}{|c|c|c|c|c|}
\hline \multirow{2}{*}{ Formulations } & \multicolumn{2}{|c|}{$\mathrm{KB}\left(\mathrm{FR}^{+}\right), \mathrm{IC}_{50}(\mu \mathrm{M})$} & \multicolumn{2}{|c|}{$\operatorname{MCF}-7\left(\mathrm{FR}^{-}\right), \mathrm{IC}_{50}(\boldsymbol{\mu M})$} \\
\hline & $3 \mathbf{h}$ & $72 \mathrm{~h}$ & $3 \mathbf{h}$ & $72 \mathrm{~h}$ \\
\hline $\mathrm{As}_{2} \mathrm{O}_{3}$ & $>200$ & $5.2 \pm 1.0$ & $63.7 \pm 22.3$ & $6.9 \pm 1.7$ \\
\hline $\mathrm{NB}(\mathrm{As}, \mathrm{Pt})$ & $>200$ & $\begin{array}{l}20.1 \pm 0.03(\mathrm{As}) \\
15.8 \pm 0.02(\mathrm{Pt})\end{array}$ & $>200$ & $\begin{array}{l}40.8 \pm 1.3(\mathrm{As}) \\
32.1 \pm 1.1(\mathrm{Pt})\end{array}$ \\
\hline f-NB(As, Pt) & $\begin{array}{l}3.3 \pm 1.4(\mathrm{As}) \\
2.6 \pm 1.1(\mathrm{Pt})\end{array}$ & $\begin{array}{l}1.2 \pm 0.01(\mathrm{As}) \\
1.0 \pm 0.01(\mathrm{Pt})\end{array}$ & $>200$ & $\begin{array}{l}34.8 \pm 4.5(\mathrm{As}) \\
27.4 \pm 3.5(\mathrm{Pt})\end{array}$ \\
\hline $\mathrm{f}-\mathrm{NB}(\mathrm{As}, \mathrm{Pt})+2 \mathrm{mM} F A$ & $>200$ & $\begin{array}{l}13.1 \pm 1.0(\mathrm{As}) \\
10.3 \pm 0.7(\mathrm{Pt})\end{array}$ & - & - \\
\hline Aqua-cisPt & $9.7 \pm 2.5$ & $1.3 \pm 0.2$ & $88.9 \pm 14.4$ & $12.2 \pm 0.4$ \\
\hline
\end{tabular}

${ }^{[a]}$ Cells were incubated with drugs continuously for $72 \mathrm{~h}$, or exposed to drugs for $3 \mathrm{~h}$, then washed and further incubated up to $72 \mathrm{~h}$ at $37^{\circ} \mathrm{C}$ in drug-free medium before IC50 measurement. IC50 values ( \pm SD) are based on As or Pt concentration $(\mu \mathrm{M})$, from 2-3 independent experiments. 